\title{
CANAL + SPAIN AND LIVE FOOTBALL BROADCASTS
}

\section{A WHOLE DIFFERENT GAME}

\author{
Vicente Rodriguez Ortega \\ Universidad Carlos III, calle Madrid 133 \\ Edificio Ortega y Gasset, Despacho 17.2.67 \\ Getafe, Madrid 28903 \\ Spain \\ vrortega@hum.uc3m.es \\ Rubén Romero Santos \\ Universidad Carlos III, calle Madrid 133 \\ Edificio Ortega y Gasset, Despacho 18.2.E.22 \\ Getafe, Madrid 28903 \\ Spain \\ rrsantos@hum.uc3m.es
}

\begin{abstract}
The main goal of Canal + Spain was to reach a significant amount of subscribers by offering programming unavailable on other channels. Following the French programming model, Canal + adopted a logic of product differentiation and technological innovation. It featured two main types of content: a diverse roster of films, shown shortly after their theatrical release, and perhaps most importantly, the innovative broadcasting of live sports events, more specifically, football.
\end{abstract}

This article focuses on sports programming in the beginning of Canal + Spain. First, it offers an account of the Spanish television landscape in the late 1980s and early 1990s. Then, it scrutinizes the arrival of commercial television within the Spanish mediascape, thus examining the launching of Canal + by paying attention to the specificity of the Spanish audiovisual market. Second, this essay analyzes the types of live sports broadcasts, focusing on football, in Canal + during the early 1990s in order to account for their importance in creating a unique kind of product designed to appeal to potential subscribers. More specifically, we will argue that live football broadcasts did not only attempt to establish a clear demarcation with the oldfashioned image and soundscapes of traditional television, but also aimed at culturally appealing to a urbanite, cultivated spectator, precisely the type of viewer Canal + tried to recruit in its early days. Therefore, we will discuss how technological excellence and spectacle became tools for the expression of specific cultural values. In short, Canal + offered a content and technology-driven "change of aesthetics" within the Spanish mediascape in the early 1990 s.

Keywords: Canal +, European television, Spanish television, football broadcasts, technology. 
V.R.Ortega and R.R. Santos, Canal + Spain and Live Football Broadcasts

\section{Introduction}

In 1988, the Law for Private Television Broadcasting was approved by Spanish parliament. Three licenses were initially awarded. Soon thereafter, in 1990, three channels started broadcasting: Antena 3, Tele 5, and against all odds, a pay channel, Canal + Spain.

The main goal of Canal + Spain was to reach a significant amount of subscribers by offering programming unavailable on other channels. Following the French programming model, Canal + adopted a logic of product differentiation and technological innovation. Its programming focused on two main types of content: a diverse roster of films, shown shortly after their theatrical release, and perhaps mostly importantly, the innovative broadcasting of live sports events, in general terms, and football, more specifically.

This article focuses on sports programming in the beginning of Canal + Spain. First, it offers an account of the Spanish television landscape in the late 1980s and early 1990s. Then, it scrutinizes the arrival of commercial television within the Spanish mediascape, thus examining the launching of Canal + by paying attention to the specificity of the Spanish audiovisual market. Second, this essay analyzes the types of live sports broadcasts, focusing on football, in Canal + during the early 1990s in order to account for their importance in creating a unique kind of product designed to appeal to potential subscribers. More specifically, we will argue that live football broadcasts did not only attempt to establish a clear demarcation with the old-fashioned image and soundscapes of traditional television, but also aimed at culturally appealing to a urbanite, cultivated spectator, precisely the type of viewer Canal + tried to recruit in its early days. Therefore, we will discuss how technological excellence and spectacle became tools for the expression of specific cultural values. In short, Canal + performed a content and technology-driven "change of aesthetics" within the Spanish mediascape in the early 1990s.

\section{Historical Overview: the Beginning of Commercial Television in Spain}

The end of the public service monopoly in Spain was a rather peculiar process. As a state with a vast majority of scholars ${ }^{1}$, there are three main features in the implementation of private TV in Spain: first it took place quite late as compared to other Western European countries such as France or Italy2; second, it was greatly realized through the arrival of foreign capital; and lastly, its creation was politically driven.

In 1980, under the government of Adolfo Suárez, the first Spanish president after the restoration of democracy in 1977, the multimedia group, Antena 3, went to court to claim its right to offer a private television. Two years later, the Spanish Supreme Court did not rule in favour of this demand. Instead, it prompted the government to regulate the market. From 1982 to 1996, the Felipe González-led Socialist Party (PSOE) was in power, but its policies towards the audiovisual market were rather unclear. Hence, since 1982, autonomous regions like the Basque Country (first) and Catalonia (later) started to broadcast through their own public TV stations (ETB and TV3, respectively). In a unique situation never seen before in Europe, Basque ETB and Catalan TV3 were financed by regional governments. As opposed to other cases such as Germany, for example, both these regional broadcasters were general interest channels. Additionally, both of them wanted to promote their specific regional languages—namely, Basque and Catalan, respectively. These stations were also financed through public money and advertising, following the unusual

1 Enrique Bustamante, Historia de la radio y la televisión en España: historia de una asignatura pendiente de la democracia, Gedisa, 2009, p. 137; Carmen Ciller Tenreiro, 'The Evolution of the Concept of Public Service and the Transition in Spanish Television', Medijska Istrazivanja/Media Research, 15, 1, 2009, 53; Manuel Palacio, Historia de la televisión en España, Gedisa, 2001, p. 172.

2 Jérôme Bourdon, Du service public à la télé-réalité. Une histoire culturelle des télévisions européennes 1950-2010. INA Éditions, 2011; Daniel C. Hallin and Paolo Mancini, Comparing media systems: Three models of media and politics, Cambridge University Press, 2004. 
model of the Spanish public broadcaster, TVE. ${ }^{3}$ Consequently, the Spanish audiovisual market was a rather chaotic scenario since these two regional channels were technically illegal. It was not until 1983 when a proper law was passed. ${ }^{4}$

The lack of a legal framework would still loom over the attempts to launch private television stations. In fact, the first private station operating in Spain was Canal 10 (Film Success S.A), an illegal satellite transmission from London that forced the government to finally create a market regulation in $1988 .{ }^{5} \mathrm{It}$ is worth noting that former Chairman of the RTVE Trust, José María Calviño, backed Canal 10 legally. What is more, a considerable (10\%) of the total stake was held by Canal + France. ${ }^{6}$ This explicitly showed, back in the late 1980 s, the French interest to get into the Spanish market. Even though Canal 10 had an ephemeral existence, it pushed the Socialist government to create a legal framework, a process that had been postponed time after time due to the Socialist Party's certain mistrust of television, explicitly acknowledged in their own documentation from 1978. ${ }^{7}$ Spain's inclusion in the European Economic Community (EEC), and the influence of some of President González's main allies, like French Prime Minister François Mitterrand, prompted a change in the PSOE audiovisual policies. ${ }^{8}$ Spain would finally regulate the arrival of commercial television. Within this scenario, Spain needed to adapt to European regulation "Television without Frontiers (TWF)," which passed in 1989. ${ }^{9}$ However, even if the EEC forced the government to liberalize the audiovisual sector and comply with the TWF directive, the PSOE government delayed its application for five years. ${ }^{10}$ This exemplifies the interventionist approach of the successive Spanish governments in regard to the audiovisual sector, a historical trend that goes all the way back to Francoism. Other scholars also point out that the demands of civil society were a key factor in the Socialist party's reconsideration. ${ }^{11}$ Therefore, two years after Spain's entry into the EEC, La Ley de la Televisión Privada (Private Broadcasting Act) was passed. ${ }^{12}$

Following the French model, three licenses were approved. Several candidates applied; licenses were issued one year later. However, in a unique case within Europe, the government did not only allow, but also actively encouraged, the presence of international investors. ${ }^{13}$ The law forbade any partner from holding more than $25 \%$ financial stake of each of the competing companies. As a consequence, national multimedia groups were stimulated to find international partners. The leading candidates moved fast. Tele 5 guaranteed $25 \%$ participation from the Italian tycoon, Berlusconi, through Fininvest. Rupert Murdoch, already a major player in the commercial TV market, also tried to enter the Spanish market through the project of Antonio Asensio and Univisión. Only Antena 3 did not include in its proposal the participation of any international companies, although it had the financial support from international investors such as Rotschild Bank. Initially, Canal + France and German Kirch Group did not appear to be interested in launching a project in the Spanish market. Things would turn out quite differently though.

As its main competitors, Javier Godó (Antena 3), Antonio Asensio (Univisión) and Grupo Vocento (Tele 5), Jesús de Polanco (CEO of Grupo Prisa) came from the journalism business. For all of them, television was the natural path to expand their multimedia interests. Polanco was the founder of El País, one of the most important newspapers of the Spanish Transition to democracy. He had close ties with Felipe González and several of his ministers in the

\footnotetext{
3 A few years later, other regions would claim their right to have their own regional channels, for example, Canal Sur (Andalucía), Canal 9 (Comunidad Valenciana), TPA (Asturias), TVG (Galicia), Telemadrid (Madrid), among others.

4 'Third Television Channel' Law 46/1983, December 26, 1983.

5 José R. Perez Ornia, La televisión y los socialistas: actividades del PSOE respecto a TVE durante la transición (1976-1981), Universidad Complutense, 1988, p. 462.

6 José María Álvarez Monzoncillo, Imágenes de pago, Fragua, 1997, p. 190.

7 José R. Peréz Ornia, La televisión y los socialistas: actividades del PSOE respecto a TVE durante la transición (1976-1981), 1998, p. 458.

8 Ramón Tijeras, 'El reparto de las televisiones privadas en España', Comunicación 21,3, 2012.

9 Richard Collins, From Satellite to Single Market: New Communication Technology and European Public Service Television, Routledge, 2005.

10 Nuria Quintana Paz, 'Políticas mediáticas de UCD y PSOE: entre el dirigismo político y la apertura mediática', Sphera Pública, 5, 2005, 160

11 Manuel Palacio, Historia de la televisión en España, 2001, p. 165.

12 'Private Television' Law 10/1988, May 3, 1988.

13 Enrique Bustamante, Historia de la radio y la televisión en España: historia de una asignatura pendiente de la democracia, 2009, p. 193.
} 
government. Upset about the $25 \%$ regulation, Jesús de Polanco played hide and seek with the government. He considered this prohibition as a handicap for his future business since his project was to expand across the Atlantic, creating a Spanish-language multimedia conglomerate. After an editorial in El País ${ }^{14}$, it looked like Jesús de Polanco was withdrawing from public tendering. Politically, this meant major troubles for the Socialist Government since Antena 3 and Univisión were considered right wing projects. It was a bluff: one month before the final date, Polanco came up with his proposal. His goal was to re-produce the success of Canal + France, which operated since 1984. It is important to realize that, after the failure of pan-European channels like Music Box, Screensport or Sky Channel, the pay TV industry was attempting to expand following two different models: News International in Great Britain and Canal + in continental Europe. While the first "got underway a satellite platform serving a single market audience," the second one "was expanding from market to market by establishing local channels with ad-hoc partners." 15 Therefore, entering the Spanish market was a natural move. Polanco's offer, though, left the government in a difficult position, as the pay TV model-terrestrial and encrypted—was not even considered within the legal framework of the public tendering process. The investors of Canal + would be Jesús de Polanco's Prisa, Canal + France, and banks such as BBV and Bankinter. These partners were powerful in financial terms but also politically. The Canal + France CEO was André Rousselet, former Chief of Cabinet of François Mitterand who, as stated above, was a close ally to Felipe González ally. In August 1989, the Spanish government ruled that the three TV stations would be Antena 3, Tele 5, and Canal +. This decision rejected Antonio Asensio and Rupert Murdoch's proposal, which was overlooked by the government due to Murdoch's support of Margaret Thatcher, an ideological enemy of Spain and France's Socialist governments. In France, Canal + would be forced to broadcast a certain amount of free-to-air and non-encrypted hours. As we will see, this practice would prove especially successful for the TV station.

Canal + would then appropriate its French counterpart's formula: cinema and sports. However, they did not take into consideration that cinema was not such a popular leisurely activity in Spain as it was in France. Conversely, football was much more popular than in the neighbouring country. Canal + Spain would also copy its corporative image and its professional organization from its French counterpart. The French know-how was not limited to content: it will also prove helpful in terms of technology (the making of decoders) and the vertical and horizontal development of the enterprise to prevent new competitors. ${ }^{16}$

\section{A Change of Aesthetics: Modern Aesthetics, Technology \& Football}

Canal + was born at a critical time in the history of contemporary Spain, becoming an important tool in projecting a modern image of a country that had underwent dramatic changes in the previous decade. Amongst them, an acute increase in Gross Domestic Product (GDP) and the appearance of a new, urban middle class were significantly important in this respect ${ }^{17}$. Canal + Spain was born as a subscription based channel that targeted the urban elites ${ }^{18}$ and consequently needed to offer an added value to its programming, differentiating itself from the broadcasting of the national public channel-TVE, regional channels such as Basque ETB and Catalan TV3 and the other two private channels-Antena 3 and Telecinco. ${ }^{19}$ In this sense, the subscriber was conceptualized as a customer (rather than a spectator) who had the privilege to access a variety of previously unscreened content-Sumo fights, documentaries about cutting edges figures such as Andy Warhol or recent independent and mainstream films, to name a few

14 'La trampa televisiva', El País, 4 July 1987

15 Jean K. Chalaby, Transnational television worldwide: Towards a new media order, IB Tauris, 2005.

16 José Maria Álvarez Monzoncillo, Imágenes de pago, 1997, p. 212.

17 Joseph Harrison, and David Corkill, D. Spain: a modern European economy, Routledge, 2016.

18 Juan Carlos Ibañez Fernández, Cine, televisión y cambio social en España, Síntesis, 2016.

19 Vicente Rodríguez Ortega and Rubén Romero Santos, 'The beginnings of Canal + Spain', 2017, https://www.youtube.com/ watch?v=Q8YKdjbAtsE 
examples - that were unavailable on Spanish free-to-air television. In addition, Canal + Spain tried to program the different shows, films and events at diverse time slots, catering to the needs of a varied demographics in terms of subscribers. ${ }^{20}$

As producer Pablo Romero Sullà explains, the director of programming, Juan Cueto, had a clear vision for what the channel should offer: "avant-garde + mainstream". ${ }^{21}$ This idea translated into the constant search for new contentsuch as the broadcasting of rugby matches or Sumo fights-but also the contemporary transformation of deeply rooted forms of entertainment within the Spanish mediascape by treating them in a different fashion, changing the aesthetic and informative approach to content-in other terms, performing a change of aesthetics in regard to content that had already been successful on Spanish television. The broadcasting of football games was central in this respect. As Sandvoss states, televised football is a hyper realistic form of narration, "as television represents the game event with ever more varying shots, angles, positions and the fragmentation of time through replays and slow motions, it constructs a new event in itself." Consequently, if one changes the narration of the event, through its visual and aural fabric, one also changes the very nature of the event itself. ${ }^{22}$

Before the arrival of Canal +, there had already been an evolution in the broadcasting of football games within the Spanish mediascape. Whereas the national channel, TVE, deployed an across the board aseptic and objective tone in broadcasting matches, in the late 1980s regional channels tried to "spectacularize" football, dedicating a significant amount of hours to both the live game and post-game shows, going deep into polemical events and breaking down in detail the different aspects of the game. In terms of technology, regional channels "added the utilization of telephoto lenses, low-angle shots, rendering a heroic image of football players, made significant efforts with in-game replays, using a dynamic tracking system that allowed to alter the speed of repetitions, deployed more dynamic editing techniques and a greater amount of close-ups and started to looked away from the field, into the stands, to increase the number of protagonists of every fixture." 23 In addition, as opposed to TVE, the regional channels approached the football match from a subjective perspective, having in-game narrators and commentators who unashamedly favoured the local team, thus adopting the point of view of the supporter within the regional territories where they broadcast.

Within this mediascape, upon obtaining the rights to broadcast the Sunday evening game, Canal + Spain further pushed the transformation of the football broadcast into a multi-layered event. This involved a series of operations that had to with both technology, the emphasis on information and in-depth coverage of games and the complementary dynamics of free/pay content. As head of sports, Alfredo Relaño, explains, this transformation was designed to follow the model of Canal + France, which had started a few years before its Spanish counterpart. In this sense, this Spanish-French Canal + exchange points to the fact the transnational dimension of European television was not limited to institutional and policy issues. Furthermore, "transnational flows and transfers take place not only across institutions and through the movement of people and programmes, but also within the production and aesthetics of programmes themselves." ${ }^{4}$ The French-Spanish axis in the broadcasting of football games is an exemplifying instance of this kind of practice.

This approach packaged content with the purpose of creating "in the spectator's mind the idea of belonging to an elite club of customers who had the privilege of access." ${ }^{25}$ In the broadcasting of live matches, this strategy of differentiation started to take shape in the treatment of the Sunday game as an event that extended well beyond the 90 minutes of play. Canal + Spain started its broadcast with the catchy and epic theme of Paul Verhoeven's

20 In addition, the "the Friday pornographic film" in Canal + became a nation-wide event. Never before had such an explicit content been broadcast in Spain.

21 Vicente Rodríguez Ortega and Rubén Romero Santos, 'The beginnings of Canal + Spain', 2017.

22 Cornel Sandvoss, A Game of Two Halves: Football Fandom, Television and Globalisation, Routledge, 2003, p. 146.

23 Antonio J. Benítez, 'Deporte y Televisión durante la Transición. Nuevos argumentos de programación deportiva utilizados en los inicios de las televisiones autonómicas', in Manuel Palacio, ed, Las imágenes del cambio: medios audiovisuales en las transiciones a la democracia, Biblioteca Nueva, 2013, p. 54

24 Andreas Fickers and Catherine Johnson, 'Transnational television history: a comparative approach', Media History, $16,1,6$.

25 Vicente Rodríguez Ortega and Rubén Romero Santos, 'The beginnings of Canal + Spain', 2017. 
Total Recall, a film that had been released that same year with considerable box-office success, setting the tone for a larger-than-life clash between the two contending sides. The pre and post game coverage included tactical commentary, interviews with protagonists and the detailed analysis of key plays of the game as well as the description, explanation and examination of polemical incidences. What Canal + offered was a "detailed-oriented and exquisite approach to content and innovative and incontestable aesthetics, attempting, at the same time, to provide the maximum amount of information while delivering spectacular entertainment."26

The Canal + football broadcasting revolution within the Spanish context also had to do with the professionals who narrated matches. Carlos Martínez' style of narration left aside the aseptic and paused tone typical of Spanish national television, championing a vivacious and lively mode of address that until then had only been typical of a different media, the radio. In regards to the tactical commentary, initially, former Real Madrid and Argentina star, Jorge Valdano, endowed the broadcast with an intellectual character, appealing to football connoisseurs beyond any partisan affiliation. After Valdano's departure to become a manager, former Irish national team and Osasuna player, Michael Robinson, took his place. Unexpectedly, Robinson's lack of fluency in Spanish became one of his greatest appeals. Passionately defending a sophisticated and offensive-minded style of play, Robinson became the unofficial spokesman of a new breed of football spectator that approached the game from both an affective and intellectual viewpoint, seeking emotional thrills but also knowledgeable satisfaction. ${ }^{27}$

Video 1. El Fútbol Canal + 1995 ("Canal + Football in 1995"). Please visit the online version of the article to watch this video.

The second stage of the revolution occurred once the game started. Under the direction of the head of broadcasting, Víctor Santamaría, Canal + pushed towards technological innovation adding sideline tracking shots, hothead cranes, small cameras, ultra slow motion images and exceptionally accurate recording devices to bring the football ground's atmosphere to the spectators' homes. In this sense, Canal + delivered an aesthetic package unseen before on Spanish television. As Santamaría remarks, "whereas on other channels I only had 7 or 8 cameras, in Canal + we used 15 or 16 in every game, even more than 20 in certain matches like Real MadridBarcelona". ${ }^{28}$ This allowed the broadcasting team to have more options in showing specific plays, covering the game from a multiplicity of angles and perspectives, and, at times, allowing the viewer to get close to the action by capturing small, yet relevant details about games. The arrival of Rupert Murdoch's channels—Sky TV and BSkyBbrought the spectacularized approach of US sports broadcasting to the old continent. ${ }^{29}$ As some authors have stated, this focus on visual entertainment will thoroughly change football. ${ }^{30}$ His main competitors-French Canal + -attempted to follow suit and transform their own broadcasts by adding further technological tools and reinventing the narrative of live sports. Most of the young Canal + Spain professionals learned their craft by studying in the United Stated in cutting edge institutions or through the connection with Canal + France. ${ }^{31}$ This approach rendered a very physical and spectacular style of broadcasting built upon the creative utilization of cutting edge technology and the commitment to give spectators detailed information. Canal +'s promotional pieces make a clear connection between the aural and visual spectacle and the technology that facilitated this approach, repeatedly showing the technological tools themselves intercut with images of games. What is more, the voiceover narration of one of these promotional videos concludes with the following statement: "A new style of broadcasting to make football a

26 Antonio J Benítez, Manuel Armenteros and Manuel Sánchez Cid, 'Pan, empresa y fútbol: los avatares del grupo Prisa para explotar los derechos de la liga española', in José Vicente García Santamaría, ed, Los procesos de 'financiarización' en los grupos de comunicación españoles y el caso Prisa-Liberty, Sociedad Latina de Comunicación Social, 2012, p. 102-103.

27 In fact, Michael Robinson continues commenting Canal + football matches up to today. He has expanded his media presence in multiple media platforms such as radio station Cadena Ser.

28 Vicente Rodríguez Ortega and Rubén Romero Santos, 'The beginnings of Canal + Spain', 2017.

29 Toby Miller, Geoffrey A. Lawrence, Jim McKay and David Rowe, Globalization and sport: Playing the world, Sage, 2001; Craig Robertson, 'A sporting gesture? BSkyB, Manchester United, global media, and sport,' Television \& New Media, 5, 4, $291-314$.

30 Richard Giulianotti, 'Playing an aerial game: The new political economy of soccer', in. John Nauright, and Kimberly S. Schimmel, eds, The political economy of sport, Palgrave Macmillan, 19-37.

31 Vicente Rodríguez Ortega and Rubén Romero Santos, 'Personal interview with Celia de Alvarado Muñoz de la Espada (Canal + Employee)', 2017. 
real spectacle." The connection between technology, the capture of images and sounds that brought the spectator closer to the game, and the idea of presenting an unprecedented audiovisual spectacle is obvious. However, Canal + also promises to get closer to the real. From their viewpoint, the beautification granted by the deployment of cutting edge technology was not the end result of their approach to football. Instead, they conceptualized it as a tool to offer a greater degree of information and access in relation to the game while enhancing the physicality of the spectators' sensorial experience during their broadcasts. ${ }^{32}$

Video 2. Así se retransmitía el fútbol hace una década, Canal +, Promotional Video about Football Broadcasts. Please visit the online version of the article to watch this video.

It is also worthwhile to remark that Canal + also broadcast free content to fulfil a legal requirement in the Spanish television law. One of the flagship programs of Canal + offer was El día después / The day after, which started on October $8^{\text {th }} 1990$, lasting until October $31^{\text {st }} 2005 . .^{33}$ Hosted by Ignacio Lewin and Jorge Valdano (Valdano was later replaced by Michael Robinson), the show reviewed the matches of the previous week, offered tactical insights on games and approached football from a humorous angle with sections like Lo que el ojo no ve / What the eye does not see, thus focusing on amusing and whimsical actions of players and supporters attending matches. Like other types of free programming, the chief function of El día después was to serve as an extended commercial for the pay content, highlighting some of the key attractions this channel had in store. Unexpectedly, the show went on to obtain spectacular audience numbers, over 2 million viewers with a $20 \%$ share. ${ }^{34}$

\section{Conclusion}

Canal + provided a new type of sensorial alphabet for Spanish television viewers, radically changing their audiovisual expectations, specifically within the broadcasting of football and also in other enduring fields within the Spanish social imaginary such as bullfighting. Within Canal + , there was a conscientious and deliberate attempt to pay close attention the aesthetic fabric of programming in order to differentiate this channel from the rest of the Spanish televisual spectrum during the early 1990s. In brief, a change of aesthetics was performed. This term has a double meaning. On the one hand, it refers to the deployment of technological tools to dramatically alter the spectator's experience of live broadcasts such as football; on the other hand, it has a cultural meaning since Canal + took well-established forms of entertainment within the Spanish social imaginary — such as football and bullfighting —and reinvented them for a new economic and political era. Spain had finally left behind the transition to democracy, becoming a full-fledged democratic country. Only two years after the launching of Canal + , Spain went through the kind of emblematic year that defines a historical period: 1992 was the year of the Barcelona Olympics, the Seville World Fair and Madrid's celebration as the European cultural capital. Symbolically, this year marked the tail end of the Spanish transition to democracy, an era of rapid and even abrupt changes in most economic, political and cultural sectors of Spain. The arrival of private networks in the early 1990s diversified the Spanish mediascape. In this regard, Canal + was a key modernizing agent as it offered new content and an unparalleled broadcasting style in the history of Spanish television.

Video 3. The beginnings of Canal + Spain. Please visit the online version of the article to watch this video.

32 See video here: 'Así se retransmitía el fútbol hace una década / This is how Canal + broadcast football', https://www.youtube.com/ watch?v=mM7ssXymgro

33 During the 1990/1991 El día después was part of the regular Canal + programming — that is, pay content-and only subscribers could watch it. Starting in the 1991/1992 football season, it was broadcast for free.

34 Vicente Rodríguez Ortega and Rubén Romero Santos, Rubén, 'The beginnings of Canal + Spain', 2017, https://www.youtube.com/ watch?v=Q8YKdjbAtsE 


\section{Acknow ledgment}

This article was written in the context of the Research Project I+D+i "Cine y televisión en España 1986-1995: modernidad y emergencia de la cultura global," Ministry of Economy and Competitiveness, Spanish Government.

\section{B i o graph y}

Vicente Rodríguez Ortega is a visiting professor at Universidad Carlos III de Madrid. He is the co-editor of Contemporary Spanish Cinema \& Genre and the author of La ciudad global en el cine contemporáneo: una perspectiva transnacional. He has published articles in New Media \& Society, Studies in European Cinema, Transnational Cinemas and Soccer \& Society and has written chapters for A Companion to Spanish Cinema, A Companion to Pedro Almodóvar, Gender meets Genre in Postwar Film, Sampling Media and Transnational Stardom: International Celebrity in Film and Popular Culture, among others. Rodríguez Ortega's interests include cinema and globalization, digital technologies and representation and film genres. He is also a member of the research group, "Cine y televisión: memoria, representación e industria" (TECMERIN).

Rubén Romero Santos is a PhD Researcher at the Department of Journalism and Media Studies at Universidad Carlos III de Madrid and has a MA degree in Mass Media Research. Recently, he has contributed to World Film Locations: Barcelona (Intellect, 2013), Ficcionando en el siglo XXI: La ficción televisiva en España (Fragua, 2016), and Tracing the Borders of Spanish Horror Cinema and Television (Routledge, 2017). Romero Santos has been working as a film and television journalist for almost two decades. He started his career at the counterculture publication, Ajoblanco, and later became editor-in-chief of the film magazine, Cinemanía. He currently combines his academic work with collaborations in magazines like Rolling Stone, ELLE, or Icon/El País and television platforms such as Canal +. Santos is also a member of the research group, "Cine y televisión: memoria, representación e industria" (TECMERIN). 